\title{
24. CRETACEOUS RADIOLARIA FROM THE WEDDELL SEA: LEG 113 OF THE OCEAN DRILLING PROGRAM ${ }^{1}$
}

\author{
Hsin Yi Ling ${ }^{2}$ and David B. Lazarus ${ }^{3}$
}

\begin{abstract}
Unusually well preserved Cretaceous radiolarians are observed in the subsurface sections from two drilled sites in the Weddell Sea collected during Leg 113 of the Ocean Drilling Program. Radiolarians from the lithified calcareous chalk of Hole 689B represent the first Campanian-Maestrichtian assemblage which is characterized by abundant Cromyodruppa ?concentrica, Dictyomitra multicostata, and Protostichocapsa stocki. Abundant Pseudodictyomitra pentacolaensis and Diacanthocapsa sp. 1, on the other hand, are the main constituents of the assemblage from the latest Aptian/earliest Albian diatomite of Hole 693B. These represent the oldest and the highest-latitude reported radiolarian occurrences from the Atlantic sector of the Antarctic Ocean. The assemblages are marked by their low diversity and an absence of low- to mid-latitude zonal indices.
\end{abstract}

\section{INTRODUCTION}

Knowledge of Cretaceous radiolarians has progressed in the last decade, with many new taxonomic and stratigraphic studies constantly being published (see Sanfilippo and Riedel, 1985 for comprehensive summary). High-latitude assemblages, however, are poorly known, particularly from the Antarctic region with few reports of moderately preserved, primarily Late Cretaceous temperate assemblages (Riedel and Sanfilippo, 1974; Pessagno, 1975; Foreman, 1978a). The recovery of unusually well preserved Cretaceous radiolarian assemblages from the Weddell Sea of the Antarctic Ocean during Leg 113 provides substantial new taxonomic, paleobiogeographic, and biostratigraphic data to fill this informational gap.

In this paper, we preliminarily document, with illustrations, the occurrence of these assemblages in the Weddell Sea and their faunal composition, while deferring the detailed discussion and presentation of new taxa until the completion of a more comprehensive comparative taxonomic analysis.

\section{MATERIAL}

Site $689,64^{\circ} 31.0009^{\prime} \mathrm{S} ; 03^{\circ} 05.996^{\prime} \mathrm{E}$, at $2,080 \mathrm{~m}$ water depth, is located near the crest of Maud Rise as an isolated elevation in the eastern Weddell Sea (Fig. 1). The moderately well preserved radiolarians were recovered only from the last core of Hole 689B of the indurated, lithified calcareous Cretaceous sequence of Lithologic Unit IIIB, Cores 113-689B-26X to -33X (236.3297.3 mbsf). Benthic foraminifers and calcareous nannoplankton suggest the age of sediments to be late Campanian(?)-early Maestrichtian (see Site 689, Barker, Kennett, et al., 1988, and Thomas et al., this volume).

Site $693,70^{\circ} 49.888^{\prime} \mathrm{S} ; 14^{\circ} 34.461^{\prime} \mathrm{W}$, at $2,360 \mathrm{~m}$ water depth, lies on the Antarctic continental slope of Dronning Maud Land (Fig. 1). Cretaceous radiolarians are found in the lowest two lithologic units (VI and VII) of Hole 693A. In the upper unit (VI) of radiolarian diatomite, Cores $113-693 \mathrm{~A}-43 \mathrm{R}$ to $-44 \mathrm{R}$ (397.8-409 mbsf), radiolarians are well preserved and abundant, while in the lower unit (VII) of dark, organic-rich claystone (or black shales), Cores 113-693A-45R to -51R (409-483.9 mbsf),

\footnotetext{
${ }^{1}$ Barker, P. F., Kennett, J. P., et al., 1990. Proc. ODP, Sci. Results. 113: College Station, TX (Ocean Drilling Program).

2 Department of Geology, Northern Illinois University, DeKalb, IL 60115.

${ }^{3}$ Geologisches Institut, ETH-Zentrum, CH-8092, Zurich, Switzerland.
}

radiolarians are rare, and variably preserved. Based on the analyses of dinoflagellates, benthic foraminifers, and calcareous nannofossils, the upper unit (VI) is considered Albian to Santonian in age, whereas the lower unit (VII) as latest Albian to earliest Albian? (see Site 693, Barker, Kennett, et al., 1988, and Thomas et al., this volume).

\section{METHODS}

Sediment samples $\left(10 \mathrm{~cm}^{3}\right)$ were broken down by boiling in $35 \% \mathrm{H}_{2} \mathrm{O}_{2}$ and $1 \%$ "Calgon" solution. Samples with high clay contents were treated with $\mathrm{H}_{2} \mathrm{O}_{2}$, dried, soaked in kerosene, and then boiled in Calgon solution. The $>63 \mu \mathrm{m}$ residue was retained for analysis.

The residue was then mounted with Canada Balsam for light microscopic study. For SEM (scanning electron microscope) observation, the residue was gold-coated after mounting on SEM stubs with double-sided adhesive tape.

Initial taxonomic analysis with a light microscope was accomplished by compiling a notebook of video-prints (Mitsubishi model P-50U). Light photomicrographs were taken with a Zeiss photomicroscope, and the location of the illustrated specimens recorded using an England Finder as described previously (Ling, 1973). All slides prepared for transmitted microscopy are located in the Micropaleontology Collection, Department of Geology, Northern Illinois University. SEM images were taken with Hitachi S-2300 and Polaroid 667 film (DL).

Relative abundance of taxa listed in Tables 1 and 2 are based on population counts of two strewn microslides (with cover glass of $22 \times 40 \mathrm{~mm}$ size): $+=$ single specimen; $\mathrm{R}$ (rare) $=2-5$ specimens; $\mathrm{F}(\mathrm{few})=6-10$ specimens; $\mathrm{C}$ (common) $=11-25$ specimens; A (abundant) = over 26 specimens.

\section{RESULTS}

Only one sample, Section 113-698B-33X, CC, was available for the present study from Hole 689B. The radiolarians are abundant and well preserved in the section (Table 1; Pls. 1-3). In spite of the abundant occurrence of known low- to midlatitude forms of Maestrichtian to late Campanian age, such as: Archaeodictyomitra ?regina, Cromyodruppa ?concentrica, Dictyomitra multicostata, Protostichocapsa stocki, Protoxiphotractus perplexus, Tholodiscus fresnoensis, T. splendensis, and Siphocampe bassilis, absence of age diagnostic species, e.g., Amphipyndax tylotus, Theocampe apicata, Alievium spp., Orbiculiforma spp., and many of the Campanian taxa, preclude assigning the assemblage to the published zonation (e.g., Emp- 


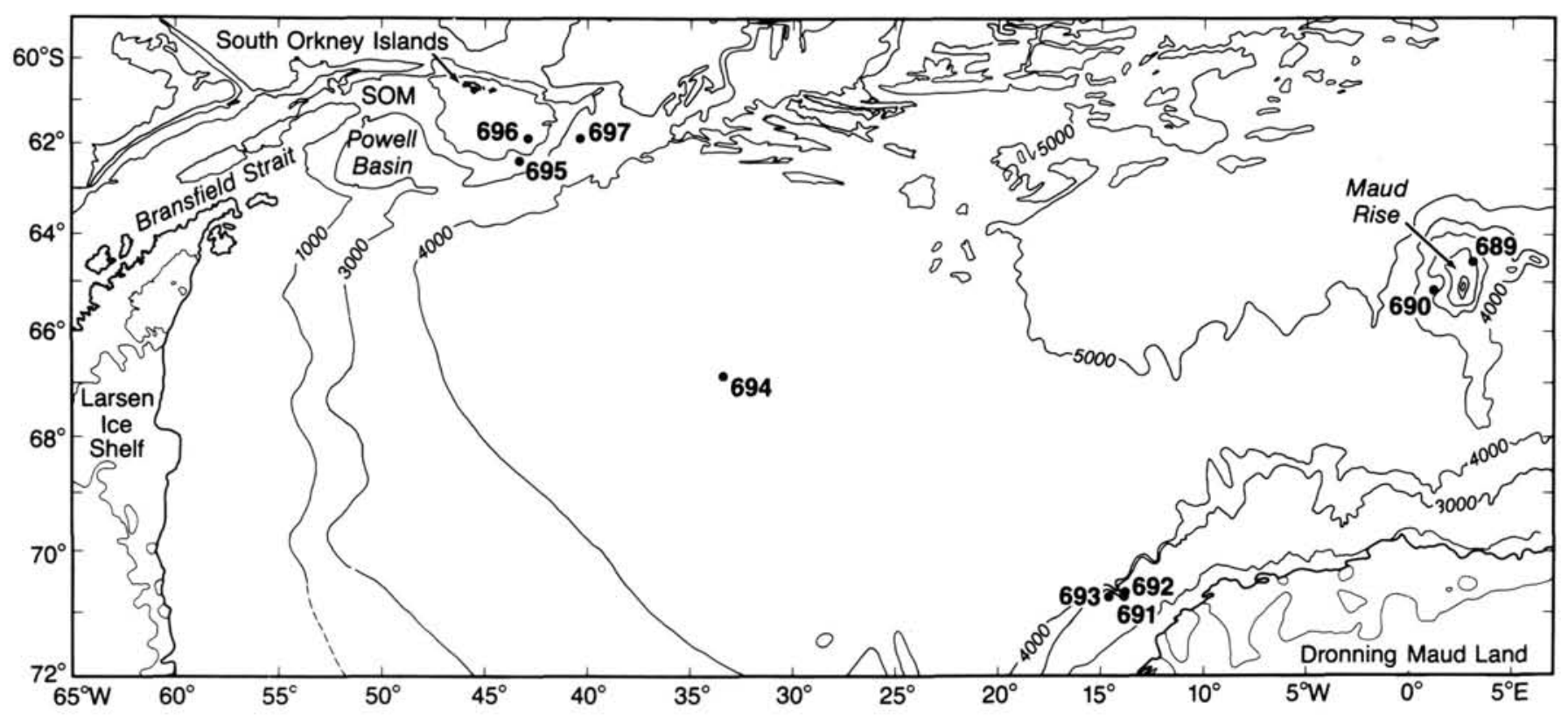

Figure 1. Location map of drilled sites (Sites 689-697) of ODP Leg 113 from Weddell Sea with solid squares indicating where occurrence of Cretaceous radiolaria was observed. Bathymetric contours at $2000 \mathrm{~m}$ interval from Tectonic Map (1985) and GEBCO sheet 5.16. SOM = South Orkney microcontinent. (After Barker, Kennett et al., 1988.)

Table 1. Occurrence of Maestrichtian (/Campanian?) radiolaria from Section 113689B-33X, CC.

\begin{tabular}{lc}
\hline \multicolumn{1}{c}{ Taxa } & $\begin{array}{c}\text { Relative } \\
\text { abundance }\end{array}$ \\
\hline Actinomma sp. & $\mathrm{R}$ \\
Amphibrachitum hastatum & $\mathrm{R}$ \\
Archaeodictyomitra ? regina & + \\
Archaeodictyomitra sp. & + \\
Artostrobus sp. & $\mathrm{R}$ \\
Cornutella california & $\mathrm{R}$ \\
Cromyodruppa ?concentrica & $\mathrm{A}$ \\
Diacanthocapsa sp. 2 & $\mathrm{R}$ \\
Diacanthocapsa sp. 4 & + \\
Diacanthocapsa sp. 5 & + \\
Dictyomitra multicostata & $\mathrm{A}$ \\
Dictyomitra sp. 2 & $\mathrm{~A}$ \\
Protostichocapsa stocki & $\mathrm{A}$ \\
Protoxiphotractus perplexus & $\mathrm{F}$ \\
Spongodiscid gen. et sp. indet. & + \\
Spongodiscus spp. (indeterminable) & $\mathrm{R}$ \\
?Stichomitra sp. D. & + \\
Theocampe altamontensis & $\mathrm{R}$ \\
Theocampe bassilis & $\mathrm{R}$ \\
Tholodiscus fresnoensis & $\mathrm{F}$ \\
Tholodiscus splendens & $\mathrm{R}$ \\
Tripodictya elegantissima & $\mathrm{R}$ \\
\hline & \\
\hline
\end{tabular}

son-Morin, 1981; Foreman, 1977, 1978; Pessagno, 1976, 1977; Sanfilippo and Riedel, 1985). However, the assemblage seems to suggest Maestrichtian in age.

Among the 14 samples examined from Hole 693A, as stated earlier, radiolarians are the best preserved and most abundant in radiolarian diatomite, Core 113-693A-44R samples (Table 2, Pls. 1-5). Their abundance sharply declines and their preservation deteriorates in Cores 113-693A-45R and -46R. Starting from Sample 113-693A-47R-2, 67-69 cm, to the lowest sample examined, Sample 113-693A-51R-2, 68-70 cm, only extremely rare specimens of taxonomically unidentifiable spongy radiolarians
Table 2. Occurrence of late Aptian/earliest Albian radiolaria from Hole 693A.

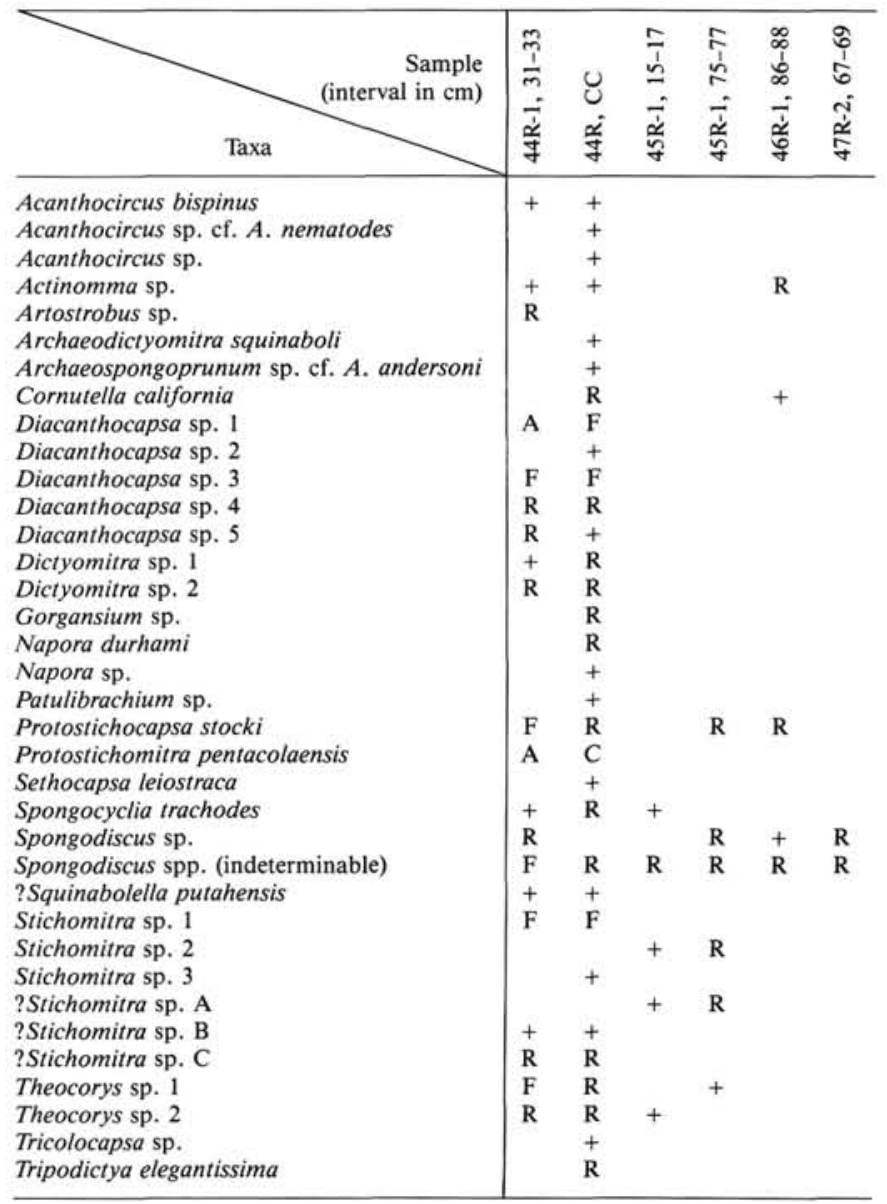


were observed. Therefore, the section can be regarded as barren for biostratigraphic purposes. Within this interval, the following samples were barren of radiolarians; 113-693A-48R-1, 143$145 \mathrm{~cm}, 113-693 \mathrm{~A}-48 \mathrm{R}-2,114-116 \mathrm{~cm}, 113-693 \mathrm{~A}-48 \mathrm{R}-2,78-80$ cm, 113-693A-48R-3, 3-5 cm, 113-693A-49R-1, 14-16 cm, 113693A-49R-2, 139-141 cm, 113-693A-50R-2, 92-94 cm, and 113693A-51R-1, 55-57 cm.

The abundant occurrence of Pseudodictyomitra pentacolaensis, and common occurrence of Stichomitra sp. A, which can be readily recognized under the transmitted light microscope, characterize this assemblage. Their presence, together with that of Napora spp., Sethocapsa leiotraca, agrees well with the Albian/ Aptian age assignment for the assemblage based on other co-occurring microfossils. Yet, it is also apparent that numerous agediagnostic forms of low- to mid-latitude regions, including Eucyrtis spp., Holocryptocanium spp., and Acaeniotyle spp. were absent from the studied samples.

\section{SUMMARY}

Thus, Cretaceous radiolarians from the Antarctic region differ from those described from low- to mid-latitude regions with respect to their lower diversity, the absence of common index species, and the presence of some high-latitude endemics. These characteristics of the Cretaceous assemblages are similar to (although not so strongly developed as) modern Antarctic assemblages, which when compared to tropical assemblages show low diversity, and presence of endemic species.

\section{ACKNOWLEDGMENTS}

We thank Michael Knappertsbusch (ETH) for his technical assistance in operating the SEM, Shihping Lin (NIU) for her photomicrographic work, Dr. Ellen Thomas, shipboard paleontologist (foraminifers), for kindly sharing some of her samples which undoubtedly sped up the completion of this manuscript, and two anonymous reviewers for their helpful suggestions on improving the manuscript. This research has been supported by ODP/NSF post-cruise funding to the authors.

\section{TAXONOMIC NOTES}

The radiolarian faunas recovered from the Leg 113 samples represent the first and oldest assemblage from the Atlantic sector of the Antarctic Ocean. Our main purpose here is to record, with illustrations (Plates 1-5), the occurrence of selected radiolarian species, together with the listing of a few references (either the original and/or the recent publication), and additional remarks wherever appropriate.

Radiolarian genera and species within a genus are listed in alphabetical order.

$$
\begin{gathered}
\text { Acanthocircus bispinus (Yao) De Wever 1984, p. } 16[=\text { Saturnalis } \\
\text { bispinus Yao, 1972, pl. 2, fig. 2]. } \\
\text { (Pl. 1, Fig. 9) }
\end{gathered}
$$

Acanthocircus sp. cf. A. nematodes Foreman.

$$
\text { (Pl. 1, Fig. 10) }
$$

In spite of the presence of an elliptical outline, a few accessory (primary?) spines suggest that the present taxon is closely related to a Californian species, A. nematodes (Foreman, 1968, p. 10, pl. 1, fig. 10). It differs from the latter in its shorter terminal (?) spine and irregularly disposed spines on the ring.

$$
\begin{gathered}
\text { Acanthocircus sp. } \\
\text { (Pl. 4, Fig. 5) }
\end{gathered}
$$

A slender and smooth ring of elongated-square outline and two polar spines which are bifurcated at the distal end characterize this species. One of the specimens under Spongosatunalis sp. aff. S. lateralis group by Renz (1974, pl. 2, fig. 1) shows similar bifurcate polar spines, but the latter possesses an ellipsoidal ring.
Actinomma sp.

(Pl. 1, Fig. 3, Pl. 4, Fig. 7)

This taxon is characterized by a spherical cortical shell which consists of a polygonal framework surrounding circular pores of nearly uniform size, and the presence of several spines made of three longitudinal ridges and grooves in long "three-blade" forms.

Amphibrachium sp. cf. A. concentricum Riedel and Sanfilippo. (Pl. 1, Fig. 14)

See discussion under Cromyodruppa ?concentrica Lipman below.

Amphibrachium ?hastatum Renz, 1974, p. 788, pl. 1, figs. 1-6; pl. 9, fig. 1.

(PI. 3, Fig. 20)

The present Weddell Sea form falls within the broad species concept illustrated by Renz (op. cit.).

Archaeodictyomitra ?regina (Campbell and Clark) Pessagno, 1976, p. 49 , pl. 14, figs. 1-3 I = Lithomitra (Lithomitrissa) regina Campbel and Clark, 1944, p. 41, pl. 8, figs. 30, 38, $40=$ Dictyomitra regina (Campbell and Clark) Foreman, 1968, pp. 68, 69, pl. 8, figs. 5a-5c]. (Pl. 2, Figs. 1, 2)

The species may be closely related to $A$. suzukii Aita (1987, p. 71, pl. 2, figs. la-2b; pl. 9, fig. 9), but differs from the latter by the cylindrical shape of post-abdominal segments.

Archaeodictyomitra? squinaboli Pessagno, 1976, p. 50, pl. 5, fig. 2-8. (Pl. 5, Fig. 8)

Archaeodictyomitra sp. (Pl. 2, Fig. 3)

The species is characterized by continuously widening abdominal segments forming a conical outline, and the presence of continuous longitudinal costae throughout.

\section{Artostrobus sp.}

(Pl. 3, Fig. 14)

Except thicker wall throughout, this species may be considered as an ancestral form of the widely documented Cenozoic form of $A$. annulatus (Bailey) Haeckel.

Archaeospongoprunum sp. ef. A. andersoni Pessagno, 1973, pp. 57-59, pl. 14, figs. 1, 2.

(Pl. 4, Fig. 2)

Cornultella californica Campbell and Clark, 1944, pp. 22, 23, pl. 7, figs. 33, 34; pl. 7, figs. 33, 34, 42, 43 .

(Pl. 3 Fig. 17)

Cromyodruppa ?concentrica Lipman, Foreman, 1978b, p. 742, pl. 2, fig. 18; I = Cromyodruppa concentrica Lipman in Kozlova and Gorbovetz, 1966, p. 62, pl. 1, figs. 1-4].

(Pl. 1, Figs. 11-13)

Four photomicrographs (Plate 1; Figs. 11-14) seem to suggest the different developmental (ontogenic?) stages for the species to Amphibrachium cf. A. concentricum (Riedel and Sanfilippo 1970, pl. 1, figs. $6,7)$.

\section{Diacanthocapsa sp. 1.}

(Pl. 3, Figs. 1, 2)

This species is characterized by a subcylindrical outline, with the thorax slightly longer than the abdominal segment, and round pores scattered throughout the surface. One of Renz's specimens identified as ?Tricolocapsa pavicola Tan Sin Hok (1974, p. 798, pl. 6, fig. 10) may be conspecific. Superficially the present form resembles $D$. normalis Yao (1979, p. 28, pl. 2, figs. 1-15), but the thoracic segment of the latter is inversely conical to show a smooth spindle outline. 


\section{Diacanthocapsa sp. 2. \\ (Pl. 3, Fig. 3)}

Similar to Diacanthocapsa sp. 1 except thoracic and abdominal segments are about the same length, and pores on the surface tend to align longitudinally between the ridges.

\section{Diacanthocapsa sp. 3.}

(Pl. 3, Figs. 4, 5; Pl. 4, Fig. 11)

The species is characterized by its subtriangular outline with maximum width near the distal end of the abdominal segment, with a tubular aperture, and randomly scattered round pores on its surface.

\section{Diacanthocapsa sp. 4. \\ (Pl. 3, Figs. 6, 7)}

Characterized by distinct lumbar stricture, superficially the present taxon is similar to the form reported as $D$. cf. ancus by Dumitrica (1970, pp. $64-65$, pl. 6 , figs. $35 a-b$, pl. 7 , fig. 40 ; pl. 20 , fig. 125 ).

\section{Diacanthocapsa sp. 5.}

$$
\text { (Pl. 4, Fig. 12) }
$$

Similar to Californian Maestrichtian form described by Foreman (1968, p. 31, pl. 4, figs. 9a-c) as Theocapsomma amphora Campbell in having irregular surface pores and much longer abdomen than that of the thoracic segment. Differs in possessing a more distinct lumbar stricture and truncated distal end of abdomen where the maximum width is located.

Dictyomitra multicostata Zittel, Pessagno 1976, p. 52, pl. 14, figs. 4-9. (Pl. 2, Fig. 4) cit.)

We follow the amended definition of the genus by Pessagno (op.

Dictyomitra sp. 1.

(Pl. 2, Figs. 5, 6)

Costae continuous throughout with two to three circular pores forming a single longitudinal row between two costae within a segment and tending to align horizontally in later post-abdominal segments. Foreman (1971, pl. 3, fig. 6) illustrated a similar specimen as one of her Dictyomitra sp. from tropical western North Pacific.

\section{Dictyomitra sp. 2.}

(Pl. 2, Figs. 7, 8)

Costae continuous throughout with three to four circular depressions in a longitudinal row between two costae within a segment and also separated by the slightly raised horizontal ridges, thus showing a regular mesh-work. The species is closely related to those illustrated by Foreman (1968, pl. 7, figs. 6a-d) as Dictyomitra andersoni (Campbell and Clark) from California. However, in her emendation of the species, she also included a few other forms presented by Campbell and Clark, and further evaluation is necessary.

The present species also shows similarity to a form illustrated as Dictyomitra sp. cf. Diplostrobus crassispina by Foreman (1978b, p. 747 , pl. 4, fig. 7), but both her illustrated specimens from California (Foreman, 1968, p. 67, pl. 7, figs. 7a, b), and the type specimen from Italy as Diplostrobus crassispina by Squinabol (1903, p. 140, pl. 8, fig. 37) possess a long (up to five segments) inversely conical distal part.

\section{Gorgansium sp.}

$$
\text { (Pl. 4, Fig. 4) }
$$

Subglobular cortical shell covered by relatively larger, circular pores of a similar size in polygonal frames, and with strong primary spines of three, alternating, long, longitudinal ridges and grooves. The three primary spines are asymmetrically arranged with two shorter spines close together.

The rare specimens recovered from Section 113-693A-44R, CC. are probably assignable to the present genus. If this is confirmed in future studies, it represents the highest known occurrence for the genus, because the range for the genus has been reported as from Upper Triassic (lower Karnian) to Upper Jurassic (Tithonian) by Blome et al (1988).
?Halesium sp.

(Pl. 4, Fig. 6)

The specimen illustrated here is structurally similar to the species illustrated by Renz (1974, p. 793, pl. 9, fig. 12) as ?Halesium quadratum Pessagno, but with distinct terminal spines at the distal end of the rays. Patagium is in an outer layer with a coarser meshwork than that of rays and is preserved(?) only in the distal two-thirds.

Napora durhami Pessagno = Ultranapora durhami Pessagno, 1977, p. 39 , pl. 5 , figs. 1-3, 13, 14; pl. 12, fig. 4 .

(Pl. 3, Fig. 15; Pl. 5, Fig. 1)

A genus Ultranapora is now considered as a junior synonym of genus Napora (Pessagno et al., 1986)

\section{Napora sp.}

(Pl. 5, Fig. 2).

Similar to the preceding taxon except subsidiary spines are absent on the cephalic horn. In this regard, the present taxon is similar to Ultranapora dumitricae (Pessagno, 1977, pp. 38-39, pl. 5, figs. 7, 16, 17, 21), but differs from the latter by a simple three-bladed horn which is gradually tapered instead of a flattened tip.

\section{Patulibracchium sp.}

$$
\text { (Pl. 4, Fig. 8) }
$$

Similar to $P$. petroleumensis Pessagno (1971, p. 37, pl. 11, figs. 2-5), but differs in surface structure of simple lattice work without knobby projections at their junction. Possesses bracchiopyles on the rays which extend into spines at the distal end.

Protostichocapsa stocki (Campbell and Clark) Empson-Morin, 1982, pl, 4, figs. 1-12 [ = Stichocapsa ?stocki Campbell and Clark, 1944,

p. 44, pl. 8, figs. 31-33 = Amphipyndax stocki (Campbell and Clark) Foreman, 1968, p. 78, pl. 8, figs. 12a-c]. (Pl. 2, Fig. 13)

Protoxiphotractus perplexus Ehrenberg, Pessagno, 1973, pp. 83, 84, pl. 15, figs. 1-3.

(Pl. 1, Fig. 1, Pl. 4, Fig. 1)

Pseudodictyomitra pentacolaensis Pessagno, 1977, p. 50, 51, pl. 8 , figs. $3,17,23$.

(Pl. 2, Figs. 9-12; Pl. 5, Figs. 5-7)

The species was proposed originally from the late Albian of California by Pessagno and was one of the most abundant species during the present study. Easily identifiable by its surface ornamentation.

Sethocapsa leiostraca Foreman, 1973, p. 268, pl. 12, figs. 5, 6. (Pl. 5, Fig. 4)

According to Foreman (op. cit.), the upper range of this species is limited to the $S$. trachostraca Zone of Valanginian to Hauterivian.

Spongocyclia trachodes Renz, 1974, pl 10, fig. 13. (Pl. 1, Fig. 7)

Spongodiscus sp.

(Pl. 1, Fig. 8)

Triangular marginal spines characterize this species and it is probably conspecific with that of Spongodiscus sp. 1 of Renz (1974, p. 796, pl. 10, fig. 17) from the eastern Indian Ocean.

\section{Spongodiscid gen. et sp. indet.}

(Pl. 1, Fig. 4)

Characterized by circular outline with three strong radial spines.

?Squinabolella putahensis Pessagno, 1969, p. 418, pl. 33, fig. 9; Renz, 1974, pl. 11, fig. 14.

(Pl. 3, Fig. 16; Pl. 5, fig. 3)

Stichomitra sp. 1.

(Pl. 2, Figs. 15, 16; Pl. 5, Fig. 11)

Following Foreman's (1968) broad concept, nassellaarians of "numerous segments, small cephalis and thorax, and no pronounced tho- 
racic ribs and wings" are placed under this generic name. Apical horn is generally present. In addition, large, elongate, hexagonal surficial pores characterize the species.

Stichomitra sp. 2.

(Pl. 2, Fig. 14; Pl. 5, Fig. 9)

Specimens of conical outline with distinct stricture between the segments, and covered by randomly distributed circular pores with polygonal frameworks are included in this species.

\section{Stichomitra sp. 3.}

(Pl 5, Fig. 10)

Similar to Stichomitra sp. B, but differs from the latter by slender conical outline with less distinct strictures.

?Stichomitra sp. A.

(Pl. 3, Figs. 12, 13)

The illustrated specimen by Renz (1974, p. 797, pl. 11, fig. 16) which was referred to as ?Stichomitra campi (Clark and Campbell) by Foreman (1968, p. 75 , pl. 8, fig. 3a-c) may be conspecific, but Foreman's specimens show a more lobate outline due to increased width in postthoracic segments.

\section{?Stichomitra sp. B. \\ (Pl. 2, Fig. 17)}

Conical outline with a continuous increase in width in post-thorax segments except for the last two which gradually constrict.

\section{Stichomitra sp. C. \\ (Pl. 2, Fig. 18)}

Conical outline except that the last segment is gradually constricted distally. Surface covered with numerous circular pores.

\section{?Stichomitra sp. D.}

$$
\text { (Pl. 3, Fig. 11) }
$$

The present specimen is provisionally placed under the genus by referring to a similar form illustrated as Stichomitra sp. cf. $S$. asymmetra by Foreman (1978b, pl. 5, fig. 1) from the Maestrichtian of California.

Theocampe altamontensis (Campbell) Foreman, 1968, p. 53, pl. 6, figs. 14a, b [ = Tricolocampe (Tricolocamptra) altamontensis Campbell in Campbell and Clark, 1944, p. 33, pl. 7, figs. 24, 26; EmpsonMorin, 1981, pl. 6, figs. la-d].

(Pl. 3, Fig. 18)

Theocampe bassilis Foreman 1968, p. 50, pl. 6, fig. 10; 1978, p. 745, pl. 5 , fig. 25 ; pl. 5 , fig. 25 .

(Pl. 3, Fig. 19)

Foreman considered the species as one of the index forms for the Maestrichtian of California.

Theocorys sp. 1.

(Pl. 3, Fig. 8; Pl. 4, Fig. 9)

Characterized by an oval outline without constrictions, and a large abdominal segment with numerous circular pores which align to the curvature of the outline. Thus, the present taxon is probably conspecific with specimens illustrated as T. antiqua by Sanfilippo and Riedel (1985, pp. 623-624, Fig. 14.6b), and T. sp. aff. T. antiqua by Renz (1974, p. 798, pl. 6, fig. 7).

\section{Theocorys sp. 2.}

(Pl. 3, Figs. 9, 10)

Smaller ovalform than the preceding Theocorys sp. 1, and with randomly distributed pores on the abdominal segment.

Tholodiscus fresnoensis (Foreman), Petrushevskaya and Kozlova, 1972, p. 525, pl. 5, fig. 1 [ = Staurodictya ?fresnoensis Foreman, 1968 , p. 14, pl. 2 , figs. la-c].

(Pl. 1, Fig. 5)
Tholodiscus splendens (Ehrenberg) Petrushevskaya and Kozlova, 1972, p. 525, pl. 18, figs. 3-5 [ = Stylodictya splendens Ehrenberg, 1875, p. 84, pl. 23, fig. 9].

(Pl. 1, Fig. 6)

Tricolocapsa sp.

(Pl. 4, Fig. 10)

Spindle-shaped, three segmented form with an expanded abdominal segment thus showing a discontinuity in outline; "basal appendage" or "extended aperture" at the distal end; surface pores, smooth, round, and numerous, tend to align in a single row between the weakly-developed ridges which start from the thoracic segment and generally conform to the outline. Thus the present species shows some resemblance to a Japanese species, T. plicatum Yao (1979, p. 32, pl. 4, figs. 1-11), but differs from the latter by the presence of much more closely spaced pores.

\section{?Tripodictya elegantissima Visassa de Regny.}

(Pl. 1, Fig. 2; Pl. 4, Fig. 3)

Superficially, the present form closely resembles the species illustrated by Renz (1974, p. 799, pl. 1, figs. 13-15; pl. 9, fig. 5) by triangular form of cortical and medullary shells, and disposition of three-bladed radial spines.

\section{REFERENCES}

Aita, Y., 1977. Middle Jurassic to Lower Cretaceous radiolarian biostratigraphy of Shikoku with reference to selected sections in Lombardy Basin and Sicily. Sci. Repts. Tohoku Univ., 2nd. Ser. (Geol.), 58:191.

Barker, P. F., Kennett, J. P., et al., 1988. Proc. ODP, Init. Repts., 113 College Station, TX (Ocean Drilling Program).

Blome, C. D., Reed, K. M., and Tailleur, I. L., 1988. Radiolarian biostratigraphy of the Otuk Formation in and near the National Petroleum Reserve in Alaska. In Gryc, G. (Ed.), Geology and exploration of the National Petroleum Reserve in Alaska, 1974 to 1982. Prof. Pap., U.S. Geol. Surv., 1399:725-776.

Campbell, A. S., and Clark, B. L., 1944. Radiolaria from Upper Cretaceous of middle California. Spec. Pap. Geol. Soc. Am., 57:1-61.

De Wever, P., 1984. Revision of Mesozoic saturnalid-type radiolarians proposition of a new classification. Rev. Micropaleontol., 27:10-19.

Dumitrica, P., 1970. Cryptocephalic and cryptothoracic Nassellaria in some Mesozoic deposits of Roumania. Rev. Roum. Geol. Geophys. Geogr.; Ser. Geol., 14:45-124.

Ehrenberg, C. G., 1875. Fortsetzung der mikrogeologischen Studien als Gesammt-Uebersicht der mikroskopischen Paläontologie gleichartig analysirter Gebirgsarten der Erde, mit specieller Rucksicht auf den Polycystiene-Mergel von Barbados. Kgl. Preuss. Akad. Wiss. Berlin, Abh. Jahrg. 1875, 1-225.

Empson-Morin, K. M., 1981. Campanian Radiolaria from DSDP Site 313, Mid-Pacific Mountains. Micropaleontology, 27:249-292.

1982. Reexamination of the Late Cretaceous radiolarian genus Amphipyndax Foreman. J. Paleontol., 56:507-519.

Foreman, H. P., 1968. Upper Maestrichtian Radiolaria of California. Spec. Pap. Paleontol. Ass. London, 3:1-82.

1971. Cretaceous Radiolaria, Leg 7, DSDP. In Winterer, E. L., Riedel, R. R., et al., Init. Repts. DSDP, 7: Washington (U.S. Govt. Printing Office), 1673-1693.

1973. Radiolaria from DSDP Leg 20. In Heezen, B. C. MacGregor, I. D., et al., Init. Repts. DSDP, 20: Washington (U.S. Govt. Printing Office), 249-304. 1977, Mesozoic Radiolaria from the Atlantic basin and its borderlands. In Swain, F. M. (Ed.), Stratigraphic Micropaleontology of Atlantic Basin and Borderlands: New York (Elsevier), 305-319. 1978a, Cretaceous Radiolaria in the eastern South Atlantic, Deep Sea Drilling Project, Leg 40. In Bolli, H. M., Ryan, W. B. F., et al., Init. Repts. DSDP, 40: Washington (U.S. Govt. Printing Office), 839-843.

1978b. Mesozoic Radiolaria in the Atlantic Ocean off the northwest coast of Africa, Deep Sea Drilling project, Leg 41. In Lancelot, Y., Seibold, E., et al., Init. Repts. DSDP, 41: Washington (U.S. Govt. Printing Office), 739-761.

Kozlova, G. E., and Gorbovets, A. N., 1966. Radiolarians of the Upper Cretaceous and Upper Eocene deposits of the Western Siberian Lowland. Tr. Vses. Neft. Naucho. Issled. Geologorazved. Inst. 248:1-159. 
Ling, H. Y., 1973. Radiolaria: Leg 19 of the Deep Sea Drilling Project. In Creager, J. S., Scholl, D. W., et al., Init. Repts. DSDP, 19: Washington (U.S. Govt. Printing Office), 777-797.

Pessagno, E. A., Jr., 1969. The Neosciadiocapsidae, a new family of Upper Cretaceous Radiolaria. Bull. Am. Paleontol., 56:377-439. , 1973. Upper Cretaceous Spumellariina from the Great Valley Sequence. California Coast Ranges. Bull. Am. Paleontol., 63:49102.

1976. Radiolarian zonation and stratigraphy of the Upper Cretaceous portion of the Great Valley Sequence, California Coast Ranges. Micropaleontology, Spec. Publ., 2:1-95.

1977. Lower Cretaceous radiolarian biostratigraphy of the Great Valley Sequence and Franciscan Complex, California Coast Ranges. Spec. Publ. Cushman Found. Foraminiferal Res., 15:1-87.

Pessagno, E. A., Jr., and Blome, C. D., 1980. Upper Triassic and Jurassic Pantanelliinae from California, Oregon and British Columbia. Micropaleontology, 26:225-273.

Pessagno, E. A., Jr., Whalen, P. A., and Yeh, K.-Y., 1986. Jurassic Nassellariina (Radiolaria) from North American Geologic Terranes. Bull. Am. Paleontol., 91:1-75.

Petrushevskaya, M. G., and Kozlova, G. E., 1972. Radiolaria, Leg 14, Deep Sea Drilling Project. In Hayes, D. E., Pimm, A. C., et al., Init. Repts. DSDP, 14: Washington (U.S. Govt. Printing Office), 495-648.
Renz, G. W., 1974. Radiolaria from Leg 27 of the Deep Sea Drilling Project. In Veevers, J. J., Heirtzler, J. R., et al., Init. Repts. DSDP, 27: Washington (U.S. Govt. Printing Office), 769-841.

Riedel, W. R., and Sanfilippo, A., 1970. Radiolaria, Leg 4 Deep Sea Drilling Project. In Bader, R. G., Gerard, R. D., et al., Init. Repts. DSDP, 4: Washington (U.S. Govt. Printing Office), 503-575. 1974. Radiolaria from the Southern Indian Ocean, DSDP Leg 26. In Davies, T. A., Luyendyk, B. P., et al., Init. Repts. DSDP, 26: Washington (U.S. Govt. Printing Office), 771-813.

Sanfilippo, A., and Riedel W. R., 1985. Cretaceous Radiolaria. In Bolli, H. M., Saunders, J. B., and Perch-Nielsen, K. (Eds.), Plankton Stratigraphy: Cambridge (Cambridge Univ. Press), 573-630.

Squinabol, S., 1903. Le Radiolariedei Noduli selciosi nella scaglia degli Euganei. Riv. It. Paleontol., 9:105-150.

Yao, A., 1972. Radiolarian fauna from the Mino Belt in the northern part of the Inuyama area, Central Japan: Pt. 1. Spongosaturnalids. J. Geosci., Osaka City Univ., 15:21-64. 1979. Radiolarian fauna from the Mino Belt in the northern part of the Inuyama area, Central Japan: Pt. II. Nassellaria 1,. J. Geosci., Osaka City Univ., 22:21-72.

Date of initial receipt: 28 February 1989

Date of acceptance: 23 August 1989

Ms 113B-133 

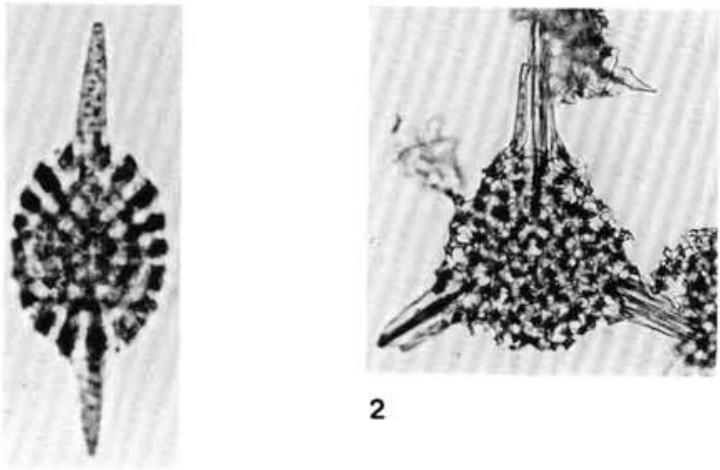

,

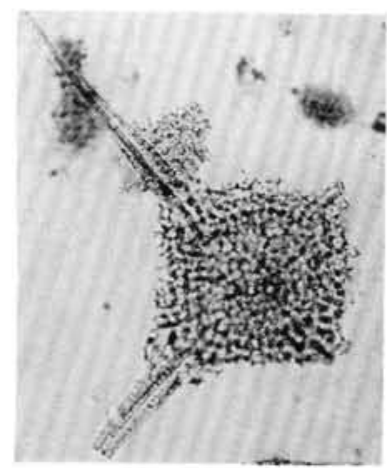

5

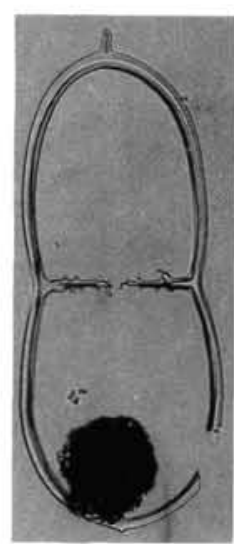

9
1

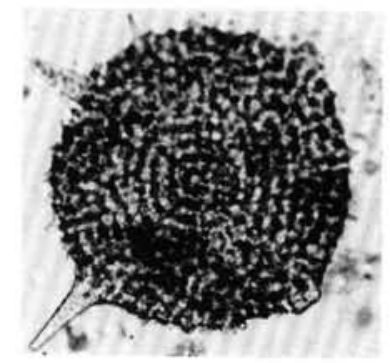

6

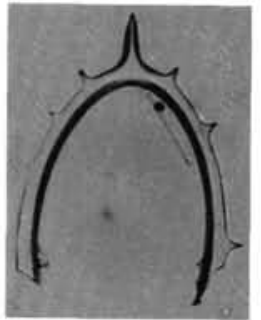

10

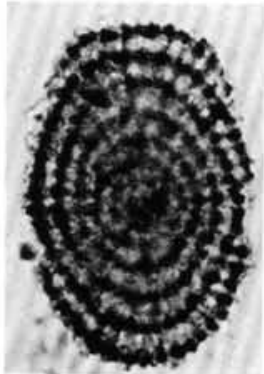

11

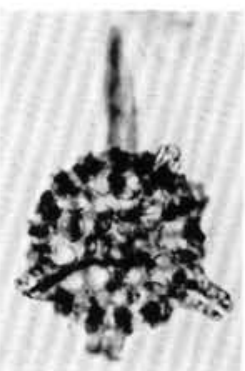

3

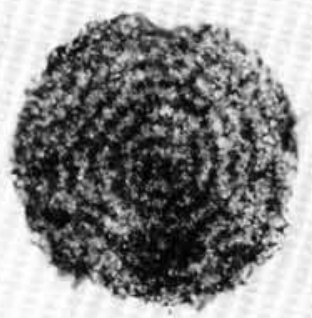

7

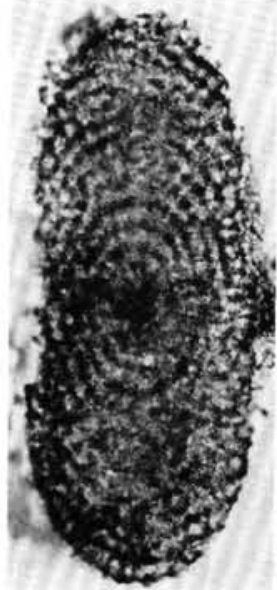

13

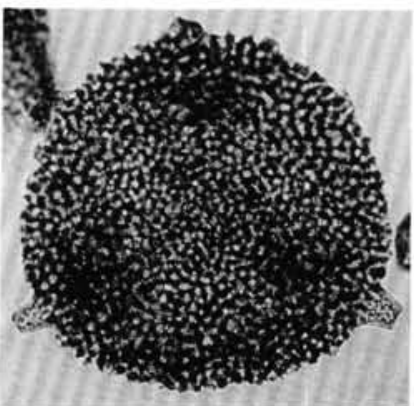

4

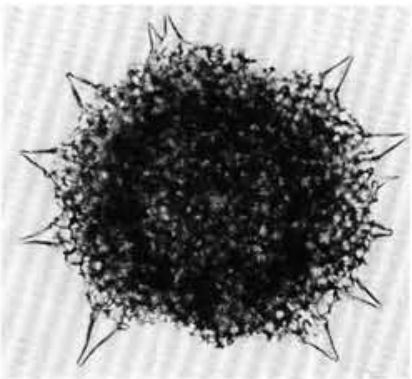

8

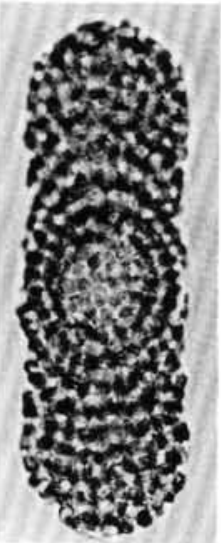

12

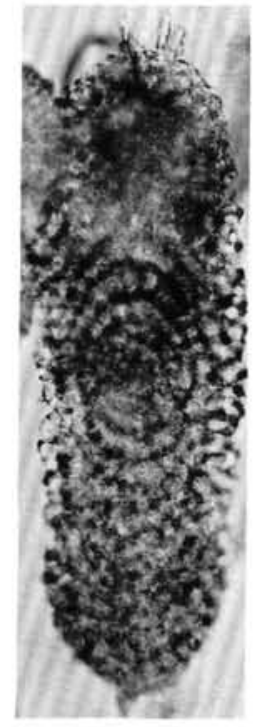

14

Plate 1. Magnification $200 \times$ unless otherwise indicated. 1. Protoxiphotractus perplexus. Section 113-689B-33X, CC. R-3 (039/4). 2. ?Tripodictya elegantissima. Section 113-693A-44R, CC. R-2 (Z17/2). 3. Actinomma sp. Section 113-689B-33X, CC. R-4 (D33/2), 160×. 4. Spongodiscid gen. et sp. indet. Section 113-689B-33X, CC. R-3 (T29/0), 125 ×. 5. Tholodiscus fresnoensis. Section 113-689B-33X, CC. R-1 (N6/4), 125 ×. 6. Tholodiscus splendens. Section 113-689B-33X, CC. R-1 (K27/0), 160×. 7. Spongocyclia trachodes. Sample 113-693A-47R-2, 67-69 cm. R-2 (K13/0), $160 \times$. 8. Spongodiscus sp. Section 113-693A-44R, CC. R-1 (D31/0). 9. Acanthocircus bispinus. Section 113-693A-44R, CC. R-2 (H23/0), 125 $\times$. 10. Acanthocircus sp. cf. A. nematodes. Section 113-693A-44R, CC, R-2, (V20/2). 11. Cromyodruppa ?concentrica, Section 113-689B-33X, CC, R-2 (029/4). 12. Cromyodruppa ?concentrica, Section 113-689B-33X, CC, R-4 (F20/1). 13. Cromyodruppa ?concentrica, Section 113-689B-33X, CC, R-4 (G35/0). 14. Amphibrachium sp. cf. A. concentricum. Section 113-689B-33X, CC. R-1 (S21/0). 


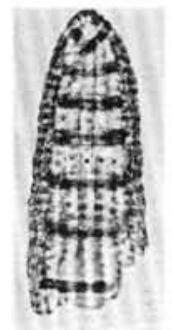

1

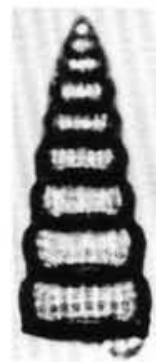

7

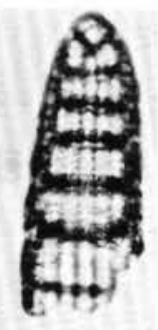

2

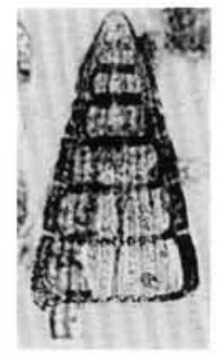

3
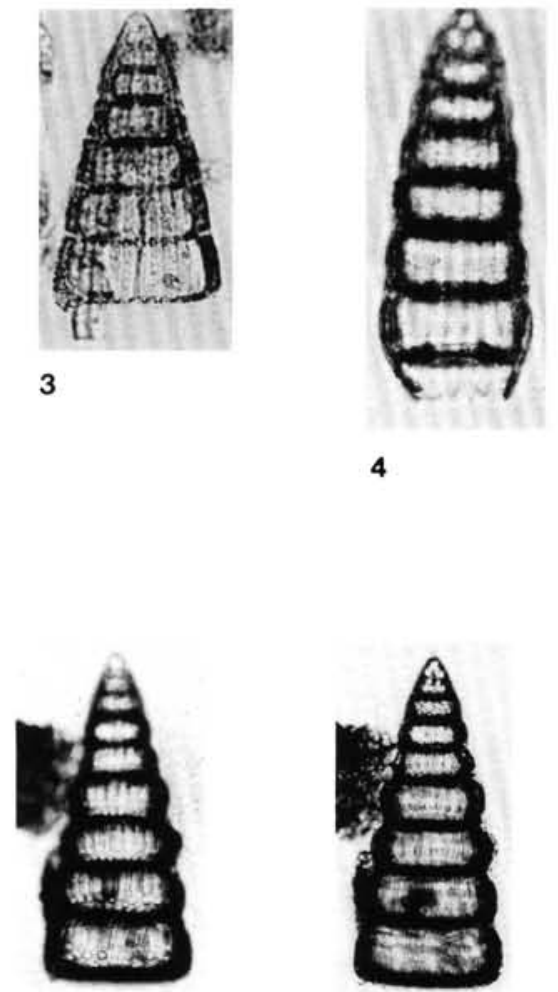

9

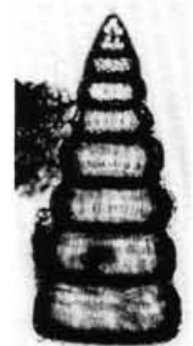

10

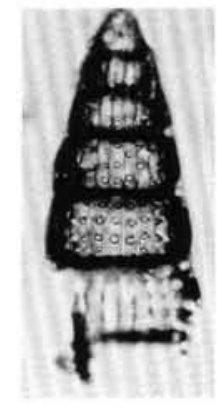

5

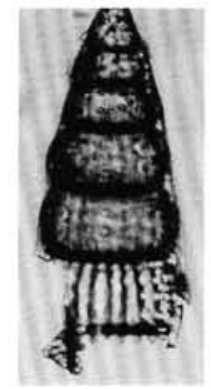

6

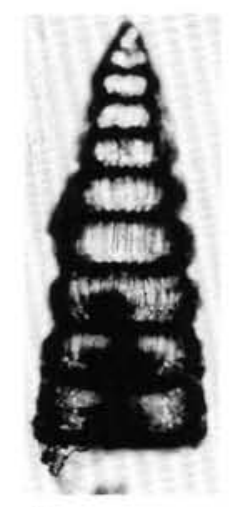

11

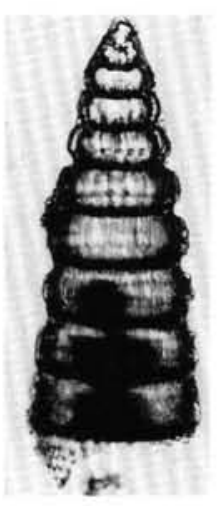

12

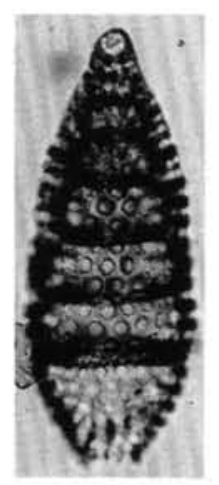

13

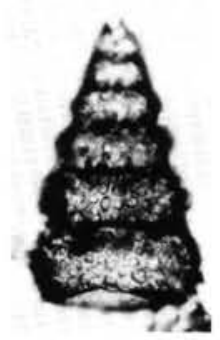

14

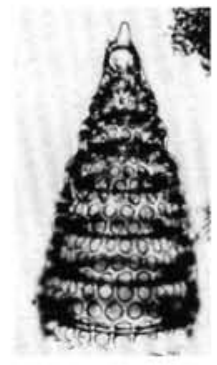

15

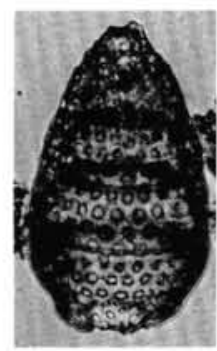

17

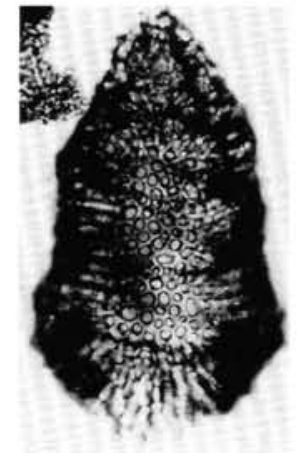

18

Plate 2. Magnification $160 \times$ unless otherwise indicated. 1-2. Archaeodictyomitra ?regina. Section 113-689B-33X, CC. R-3 (S26/2), 200 $\times$. 3. Archaeodictyomitra sp. Section 113-689B-33X, CC. R-3 (S22/3), 200×. 4. Dictyomitra multicostata. Section 113-689B-33X, CC. R-1 (06/0), 200 $\times$. 56. Dictyomitra sp. 1. Section 113-693A-44R, CC. R-1 (J14/2). 7-8. Dictyomitra sp. 2. Section 113-689B-33X, CC. R-4 (Q4/4). 9-10. Pseudodictyomitra pentacolaensis. Section 113-693A-44R, CC. R-2 (J35/0). 11-12. Pseudodictyomitra pentacolaensis. Section 113-693A-44R, CC, R-1 (H30/0). 13. Protostichocapsa stocki. Section 113-689B-33X, CC. R-4 (F23/0). 14. Stichomitra sp. 2. Sample 113-693A-45R-1, 75-77 cm. R-2 (W27/0). 15-16. Stichomitra sp. 1. (15) Section 113-693A-44R, CC. R-1 (K16/1); (16) Section 693A-44R, CC. R-2 (040/1). 17. ?Stichomitra sp. B. Sample 113-693A-44R-1, 31- 33 cm. R-2 (Q4/0), 250×. 18. ?Stichomitra sp. C. Sample 113-693A-44R, CC. R-2 (P27/2). 


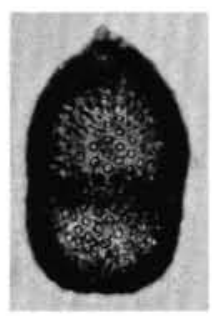

1

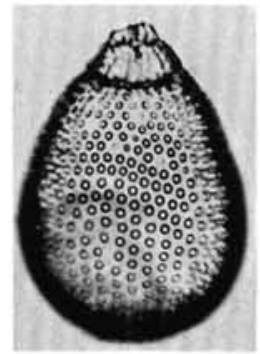

8

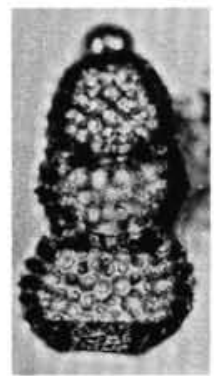

11

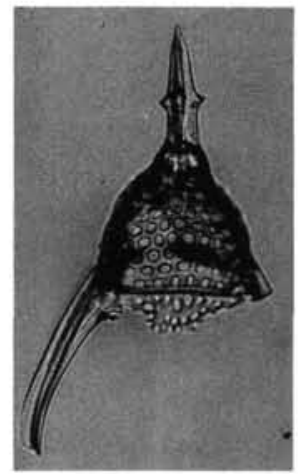

15

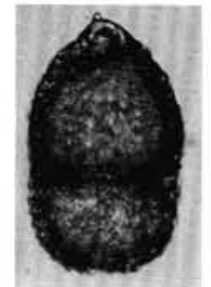

2

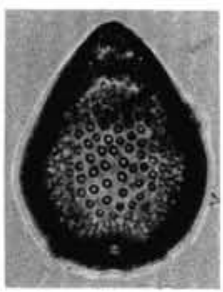

9

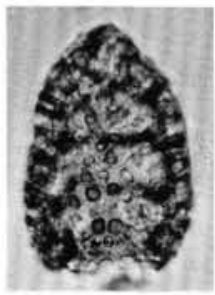

12

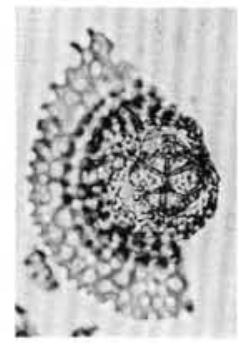

16

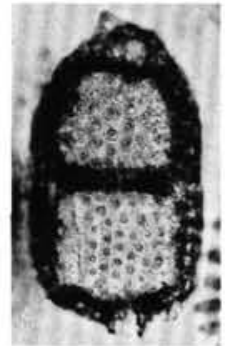

3

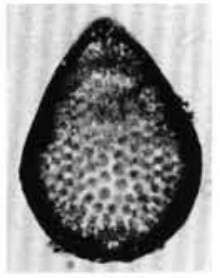

10

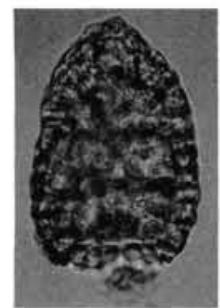

13

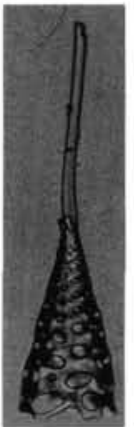

17

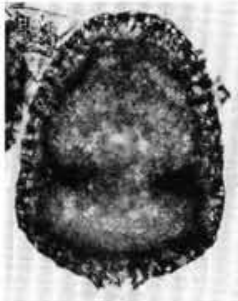

4

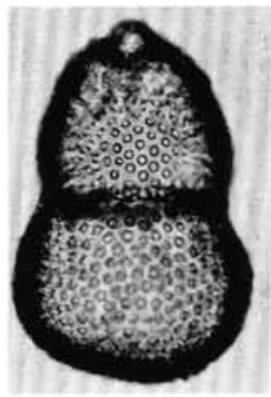

6

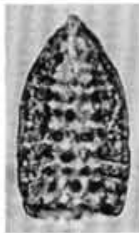

14

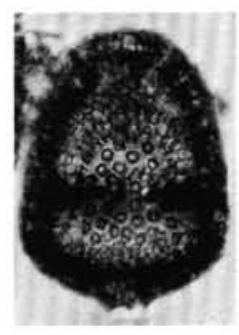

5

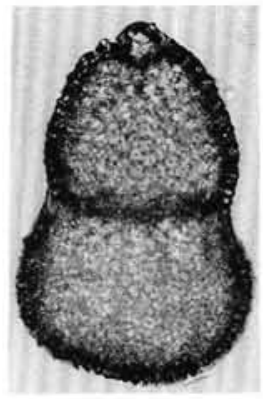

7

Plate 3. Magnification $200 \times$ unless otherwise indicated. 1-2. Diacanthocapsa sp. 1. Section 113-693A-44R, CC. R-2 (Z17/2), 250×. 3. Diacanthocapsa sp. 2. Section 113-689B-33X, CC. R-3 (Y3/2). 4-5. Diacanthocapsa sp. 3. Sample 113-693A-44R-1, 31-33 cm. R-1 (T29/0), 250× . 6-7. Diacanthocapsa sp. 4. Sample 113-693A-44R-1, 31-33 cm, R-1 (E12/2). 8. Theocorys sp. 1. Section 113-693A-44R, CC. R-2 (K18/1). 9-10. Theocorys sp. 2. Section 113-693A-44R, CC. R-1 (E12/2), 250×. 11. ?Stichomitra sp. D. Section 113-689B-33X, CC. R-3 (F12/1). 12-13. ?Stichomitra sp. A. Sample 113-693A-45R-1, 75-77 cm. R-2 (X34/3), 250×. 14. Artostrobus sp. Section 113-689B-33X, CC. R-3 (M14/3). 15. Napora durhami. Section 113-693A-44R, CC. R-2 (D15/0). 16. ?Squinabolella putahensis. Sample 113-693A-44R-1, 31-33 cm. R-1 (G3/0). 17. Cornultella californica. Section 113-693A-44R, CC. R-2 (027/0), 160×. 18. Theocampe altamontensis. Section 113-689B-33X, CC. R-2 (H4/0). 19. Theocampe bassilis. Section 113-689B-33X, CC. R-3 (N17/2). 20. Amphibrachium ?hastatum. Section 113-689B-33X, CC. R-1 (N18/2), 125 $\times$. 


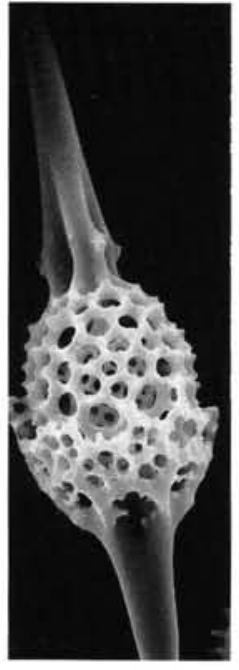

1
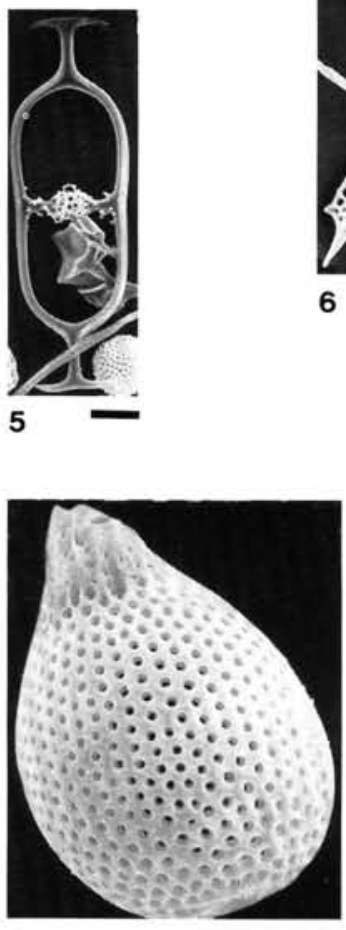

9

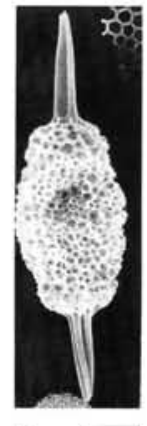

2

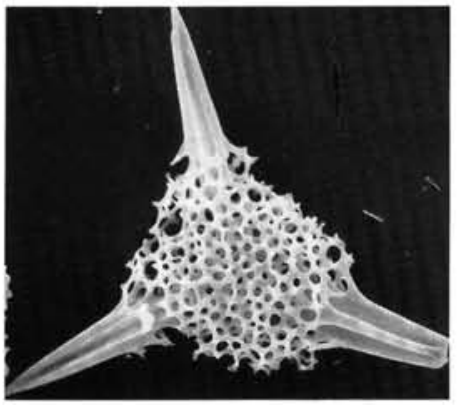

3

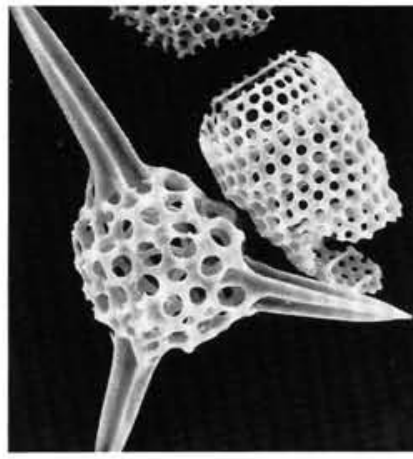

4
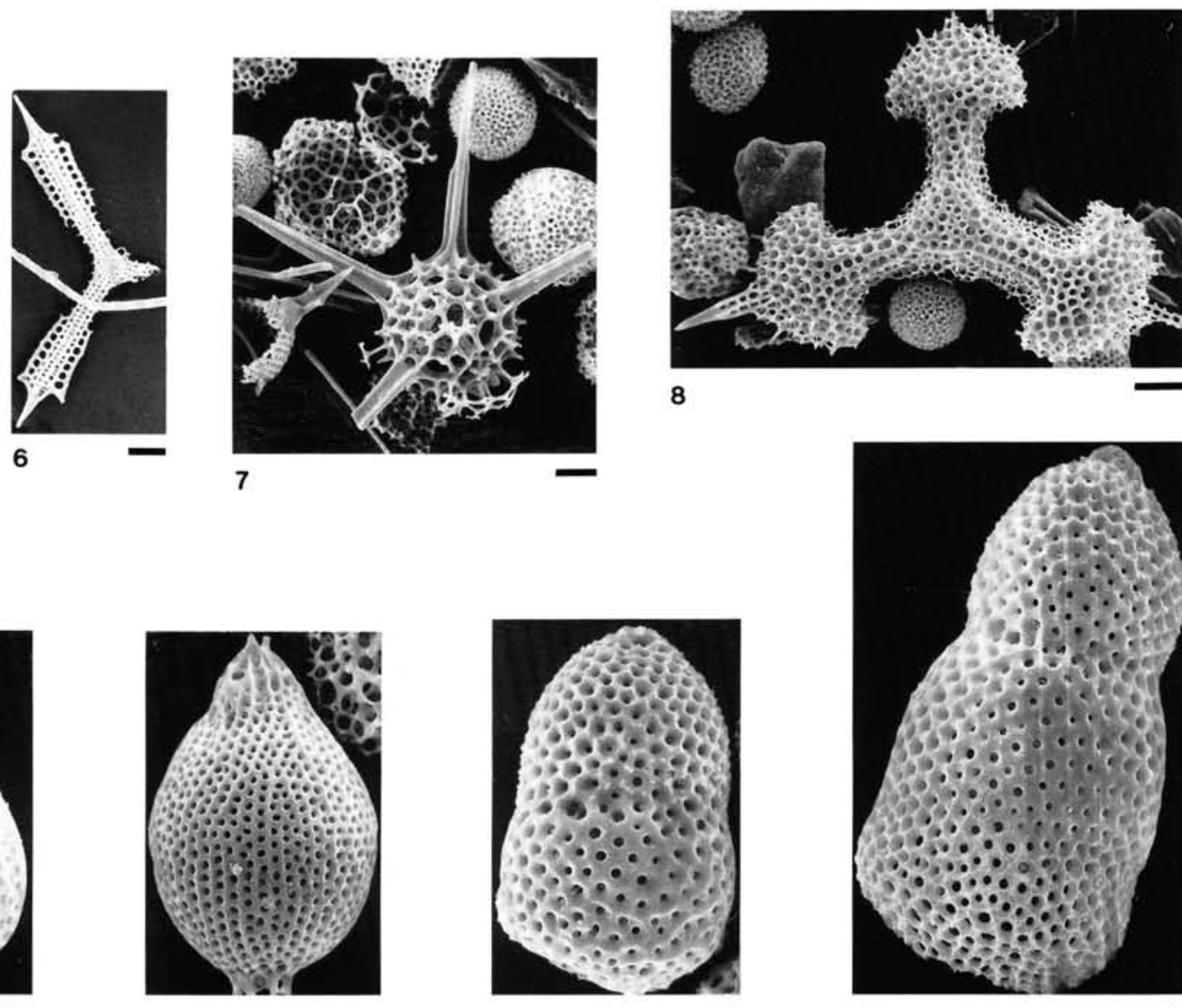

12

Plate 4. All the specimens are from Section 113-693A-44R, CC. Scale bar $=50 \mu \mathrm{m} . \quad$ 1. Protoxiphotractus perplexus. 2. Archaeospongoprunum sp. cf. A. andersoni 3. Tripodictya ?elegantissima. 4. Gorgansium sp. 5. Acanthocircus sp. 6. ?Halesium sp. 7. Actinomma sp. 8. Patulibracchium sp. 9. Theocorys sp. 1. 10. Tricolocapsa sp. 11. Diacanthocapsa sp. 3. 12. Diacanthocapsa sp. 5. 


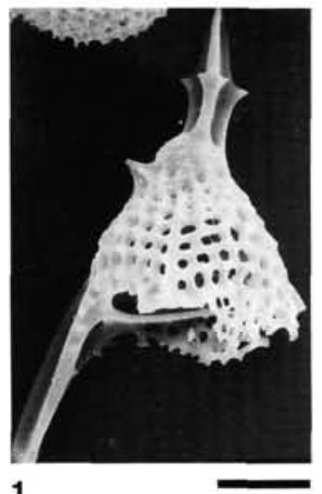

1
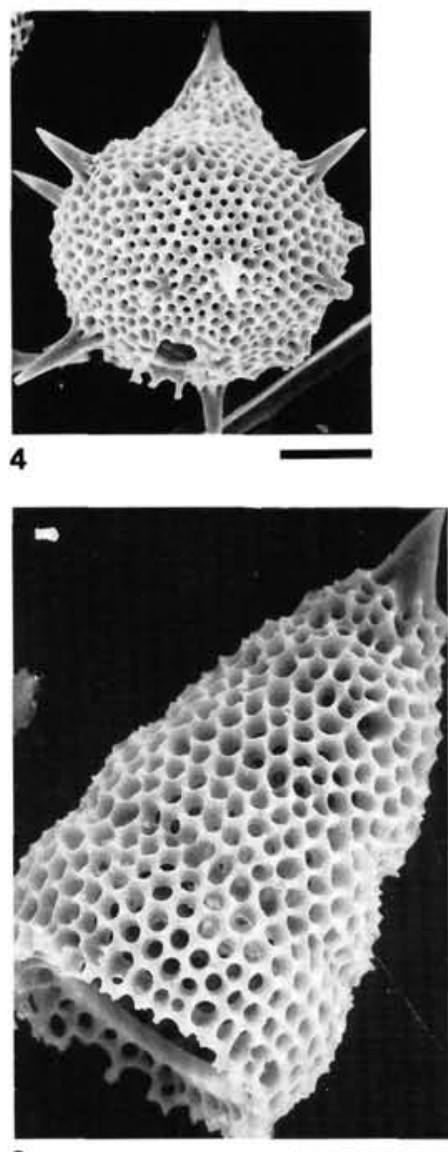

9

2
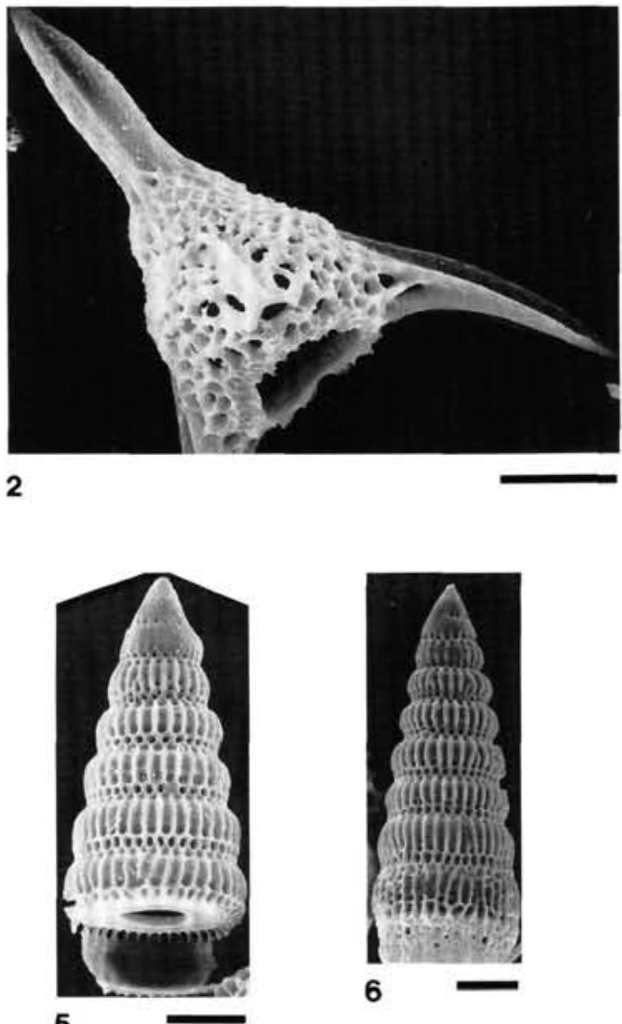

5

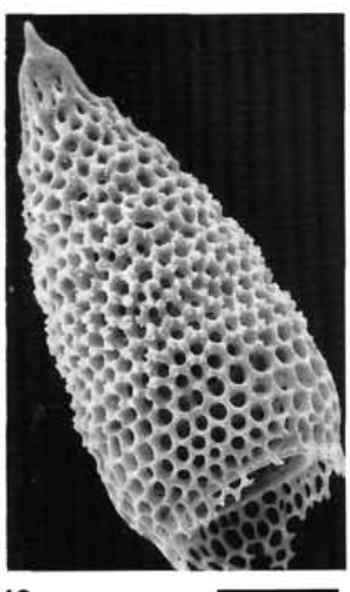

10

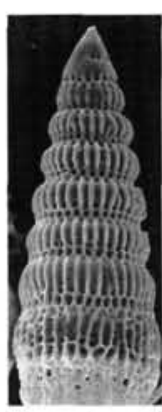

6

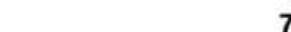

7
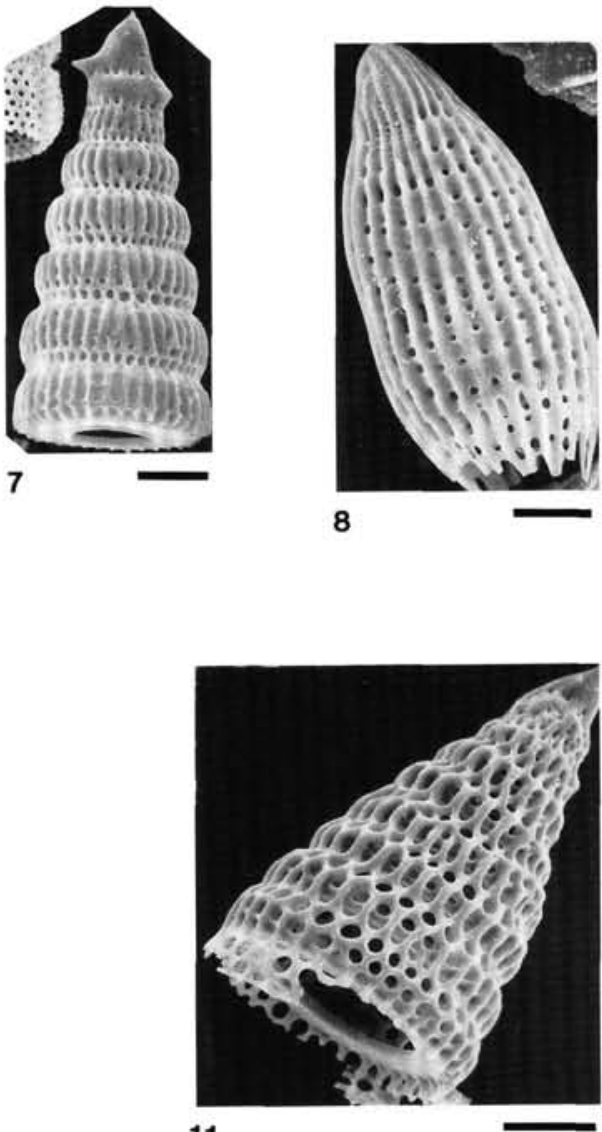

11

Plate 5. All the specimens are from Section 113-693A-44R, CC. Scale bar $=50 \mu \mathrm{m}$. 1. Napora durhami. 2. Napora sp. 3. ?Squinabolella putahensis. 4. Sethocapsa leiostraca. 5-7. Pseudodictyomitra pentacolaensis. 8. Archaeodictyomitra squinaboli. 9. Stichomitra sp. 2. 10. Stichomitra sp. 3. 11. Stichomitra sp. 1. 